\title{
LEGAL TECH IN LEGAL EDUCATION: GLOBAL PERSPECTIVES AND CHALLENGES FROM THE LATVIAN - UKRAINIAN EXPERIENCE
}

\author{
Karina Palkova \\ Riga Stradins University, Latvia \\ Olena Agapova \\ National Scientific Center “Hon. Prof. M.S.Bokarius Forensic Science Institute”, Ukraine
}

\begin{abstract}
The paper examines legal rules covering the legal industry and the field of legal education against the background of fast-growing innovation technology and it's influence. The field of legal education faces with several transformation processes. Thus, educators should be ready to prepare law students for innovations in the legal field as well. The era of legal technology (or "Legal Tech") is becoming a crucial element of modern lawyers. According to several reports, Legal Tech brings new trends for a lawyer. Such profession faces new challenges, therefore from the educational point of view it is important to prepare students for those changes. The work on national and global level in the field of policy planning documents is needed. Authors found out that nowadays legal education has a weakness that relates to insufficient cooperation with such vital elements as technology and innovation. Law science and technology cannot be considered separately taking into account changes in the global disciplines. Legal Tech in the legal education system can be implemented on several educational levels. Legal Tech education should take part on university level to instill in young lawyers a taste for progressive technologies from the student's bench.
\end{abstract}

Keywords: education, future, Legal Tech.

\section{Introduction}

Technology and innovations are changing the concept of legal services and the deliverability of particular services. The world in common as well as the world of legal services are becoming virtual. Technologies provide more unique opportunities for lawyers, but the question is are lawyers, society, and educational systems ready to accept them. Digitization already has an impact on legal issues. McGinnis and Pearce reckon that the disruption of the legal profession has begun and that technological acceleration will have significant implications for both legal practice and legal education (McFaul, FitzGerald, Byrne et al., 2020).

Nowadays, the law profession is more advanced than the law school model. Law schools still provide $20^{\text {th }}$ century skills knowledge to the students. Nevertheless, the legal profession with the technological progress is more 
compliant to 21st-century system. There is a lot of practical legal work that can be done by special technologies, systems, and machines. The same situation is with the document analyzing process and legal research. There is no need anymore to review a large number of legal documents, case law, etc. New technologies provide this option (Corrales, Forgo, \& Kono, 2020).

From the authors point of view, it is significant to identify and clarify the importance of modern and developed legal educational systems. Considering the new technological trends, Legal Tech, fast-growing artificial intelligence and the opportunities they provide, there is a need for lawyers who work with the systems. Modern or future lawyers are persons who can solve the problem of the client with regard to the data provided by the mechanisms. Legal Tech is the way to achieve the goal and provide competitive services to advanced clients. Some scientific resources provide the definition "legal knowledge engineer". Authors agree with the idea of a new concepts of legal knowledge, because modern as well as future lawyers will be the people who will work with the development of new ways of solving legal problems. And with the "new ways" authors understand technological support in the legal profession.

The development and usage of new educational technology (hereinafter EdTech) and Legal Tech can drastically transform the legal education system. The implementation of the Legal Tech tool in the system of higher legal education requires joint efforts of the representatives of different law schools, legal practitioners, and IT specialists. We consider the issues of improving legal education in Ukraine and Latvia, the legal background, and the first steps taken towards the implementation of Legal Tech to be relevant and that they require to be discussed in detail by the representatives of the academic community (Ryan, 2020).

Does it mean that the implementation of EdTech and Legal Tech can fully replace "traditional training" of law students? It is obvious that the development of educational technology requires adjustment to new conditions of training, and that legal education must adopt to it and implement certain Legal Tech tools.

We firmly believe that the only way to get new forms of training legal students is to combine EdTech and Legal Tech. The aim of the research is to investigate factors associated with the Legal Tech in Latvian and Ukrainian legal education systems.

For the purposes to achieve the aim of the research, the authors will use general scientific methods. The authors will make the legal analysis of national, international documents. To complete the research, authors will use general scientific methods such as synthesis, comparative method, and deductive methods.

The theoretical base of the study is constituted by contemporary scientific works and articles of national and international authors. As well as scientists' 
views who have provided a global contribution to the development of Legal Tech in the educational systems will be considered and analyzed.

\section{Research}

Future developments of legal digital transformation give a lot of advantages, as well as provide new challenges for legal education. Examples mentioned before illustrate the application of Legal Tech in practice and show how to automatized workflows, artificial intelligence, automatized generation of documents are in use today and will be used in the future (Hartung, Bues, \& Halbleib, 2018).

The legal market is changed. As well the work of nowadays layers becomes more technological. Legal Tech is an important instrument to increase the potential of lawyers. New technologies make changes in lawyers' professional lives. Legal Tech is as assisting programme for lawyers. And provide them legal services much faster. The advantage is the cost efficiency as well. Legal Tech in practice can make the matter more efficient and profitable. Many national, as well as international legal firms use the technological progress for reasons mentioned before. Legal market has new challenges - new branches of laws, new types of legal transactions, technological progress, fast -changing legislation, the law can't keep up with new technologies anymore etc. The advantage of Legal Tech is the fast research of the legal problem, the possibility to adapt to the changes in the legislation field, the automatization of the management, and customer or clientbased approach (the communication with the clients).

Law students starting studies at a university deal with particularly new challenges. Fast growing changes into the law industry influence the content of the study. At the same time, new skills are needed to be prepared for the lawyer profession transformation (Hartung, Bues, \& Halbleib, 2018). Nowadays, the issue of artificial intelligence and artificial intelligence technology in the context of lawyer's duties is not futuristic anymore. Artificial intelligence programs help law firms with contract management and contract drafting. Softwares can provide standardized contract templates that, for instance, can be based on previous years' experience, past legal disputes, etc. (Betts \& Jaep, 2017). The same situation is with legal chatbots that help with lawyers in the consulting sphere. Therefore, there are new accents in the law education system shall be made. The skills that the lawyers of $21^{\text {th }}$ should gain are collecting contract performance data, ethical issues on artificial intelligence usage in legal practice etc. (Andrade, 2020).

Digital transformation (digitalization) is a driving force for legal occupation and it requires a different set of skills and capabilities than those traditionally taught in law school or used in legal practice. 


\section{EdTech}

Legal Tech
New forms of training legal students

Figure 1 Legal Tech Scheme

Tanner Mirrlees and Shahid Alvi (2020) also discuss the issue of transforming higher education under the conditions of the «digital age»: «But has digital technology produced a "digital age" that compels society and all of its universities to undergo or adapt to a profound change?» (Mirrlees \& Alvi, 2020). While current digital developments are accompanied by projections of and often pleas for revolutionary change in higher education, we do not believe that a technology-determined "digital age" is the fundamental cause of the contemporary transformation of higher education in the early 21st century. Higher education and digital technology are part and product of society, and in any age they will express society's broader economic, political, and ideological conditions (Mirrlees \& Alvi, 2020).

Within this context, it is necessary to consider certain approaches to understanding the concept EdTech. Clear definitions of the term are in short supply, and this is largely because the meaning of the technology itself "is messy and complex" (Hughes, 2004); it has been often described as "the knowledge and instruments that humans use to accomplish the purposes of life" (Friedel, 2007). The meaning of "digital technology" is no less clean and simple, as this phrase is frequently an umbrella for the totality of devices (hardware), applications (software), and platforms enabling the creation, circulation, storage, retrieval, manipulation or reception of digital content. Current ideas of EdTech are also multifaceted (Mirrlees \& Alvi, 2020).

They tend to encompass three currents: an academic discipline usually housed in faculties, departments, and programs associated with "education". An educational "design science" or mode of educational governmentality for developing, carrying out, and evaluating the whole process of teaching and learning, with the goal of improving educational performance or a subject's conduct of educational conduct. It shall be noted, that the digital technologies used by teachers and learners for the means and ends deemed "educational." (Moller, Huett, \& Harvey, 2009). In much popular discourse, and throughout much of this book, EdTech tends to denote an industry and commercially available digital technologies used by teachers and learners for the means and ends of something called “education” (Mirrlees \& Alvi, 2020).

In order for new education technologies to be actually embodied and used in the learning process, Michael Spector suggested that "educational technologists" 
follow the so-called "Educational Oath" in their work, kind of like the Hippocratic Oath:

1. Do nothing to impair learning performance and instruction.

2. Do what you can to improve learning performance and instruction.

3. Base your actions on the evidence that you and others have gathered and analyzed.

4. Share the principles of learning, performance, and instruction that you have learned with others.

5. Respect the individual rights of all those with whom you interact.

Summarized, it summons us to improve education (and not hinder it), to use evidence from research and practice, to share, and to respect others (Spector, Ohrazda, Van Schaack, Wiley, 2005).

It is obvious that legal education cannot stand aside from educational technologies and new technological tools that are actively used in legal practice. A modern law student must acquire a set of Legal Tech skills during the study.

M. Fenwick, W.A. Kaal, E.P.M. Vermeulen think that the introduction of a Coding for Lawyers course into our legal education programs is highly appropriate. They are convinced that coding can help in solving many contemporary economic, environmental, and social issues. Such skills can help «the lawyers of the future» to understand and communicate with programmers. This is why law students will benefit on understanding the basic concepts and power of coding (Fenwick \& Kaal, 2020).

To make the analyses of the current situation in the field of Legal Tech authors decide to compare Latvia and Ukraine experience. Latvia is the EU country with the fast growing technological - digital potential. Ministry of Environmental Protection and Regional Development of Latvia work on "Digital Transformation Guidelines for 2021-2027”. The document sets long-term priorities and strategic guidelines for the country's digital development and changes to be implemented in all areas of the economy and life in order to ensure the digital environment (Ministry of Environmental Protection and Regional Development of the Republic of Latvia, 2021). But Ukraine in non EU country that according to the Legal Tech project catalogue has up to 50 Legal Tech projects at the Ukrainian market. Legal Tech development in Ukraine is at the initial stage but still there are fast growing market. Theme of present article is not so much discussed in the academic literature in Latvia, but it must be noted, that the lawyer's profession involves both providing legal aid to others persons in the protection of their rights and taking a nationally important positions. It is vital that the demands of a lawyer qualifications are high enough andmodern from the development perspective (Grasis, 2020). The new system of National Uniform Professional Legal Qualification Examination for lawers shows the necessity to transform the study process, to make changes in the study courses, and this is the 
good opportunity for Legal Tech implementation in the study process (Vilks, 2019).

According to paragraph 4, part 1 of the Presidential Decree dated 30.09.2019 №722/2019 "On the Sustainable Development Goals of Ukraine until 2030" ensuring inclusive and quality education and encouraging lifelong learning opportunities for all are defined as guidelines for the development of draft forecast and program documents, draft regulations in order to ensure sustainable development of Ukraine for the period up to 2030 (President of Ukraine, 2019).

Cabinet of Ministers of Ukraine Resolution dated 12 June 2020 № 471 "On approval of the Programme of Activity of the Cabinet of Ministers of Ukraine" defines the need for comprehensive reform of higher legal education and preparation of educational institutions for the educational process in a pandemic (2020-2021) is determined. (Cabinet of the Ministers of Ukraine, 2020) To implement this Order, the Concept for the Development of Legal Education was developed and discussed at the working meetings of the people's Deputies of Ukraine together with experts in the field of law and higher education. It should be noted that this concept defines the state of modern legal education in Ukraine and the ways of its improvement (Komitet Verhovnoj Radi Ukraini, 2020).

Thus, the concept for the development of Legal Education demonstrates the inconsistency of the content of legal education and the quality of training in law schools with modern labor market requirements and challenges facing modern democratic society, global development trends, and the task of lawyers in various fields. The content of legal disciplines taught in the law schools of Ukraine, methods of teaching legal science, as well as the administration of these schools and universities, in general, is slowly undergoing qualitative changes, and remain to be a legacy of the Soviet legal education system, according to which a lawyer is perceived as a person summoned to serve the state, rather than a guarantee, assert and protect human rights or ensure effective public prosecution. Because of this, forming the legislative area for the activities of legal institutions following European standards, the state does not get specialists who can implement new laws for the assertion and protection of human rights (Abroski, 2020).

The concept of the development of legal education as a guiding document of state policy in the field of legal education consists of so-called strategic goals. It is planned that the gradual achievement of these goals will help improve the training of future lawyers. We would like to give a positive notice to the activities of the legal community directed at launching a strategic document, which provides for certain issues of the use of Legal Tech in legal education.

We offer to get acquainted in more detail with the main strategic goals and their compliance with modern requirements relating to the implementation of Legal Tech in the educational process. 
Strategic goal № 5 "Law schools ensure that higher legal education students acquire a high level of applied practical skills and abilities”. According to this goal, the active introduction of innovative forms and methods of teaching into the educational process is envisaged: cases, educational court hearings, etc.

Strategic goal №10 "Law schools are powerful centers of scientific, educational, and innovative development." It should be emphasized that within the framework of this goal, it is planned to provide legal education seekers with access to educational resources including recognized professional databases, international informational, scientific and practical, library, and other resources.

We have reason to note that the draft Concept for the Development of Legal Education indirectly mentions the need to implement certain tools of Legal Tech during the training of law students (use of educational resources, practical cases, training court hearings) (Komitet Verhovnoj Radi Ukraini, 2020). However, there is no legal act that regulates the issue of consistent implementation of Legal Tech in training programs for lawyers.

Latvian Education Law (Education Law, 1999) demonstrates the positive tendency in developing education from the technological perspective. The Law provides information on technical teaching aids (technical equipment and devices to be used in the learning process, including technical equipment and devices provided for educates with special needs), the use of individual learning accessories, as well as technologies. The new lawyer's professional standard in Latvia should be mentioned as well. According to the standard, a lawyer should have general knowledge on Information technology law. The students during the education process should be educated more on technology. Nevertheless, it is universities that play the substantial role in training future lawyers and legal tech implementation during the educational process. The content of the legal programs depends on both international and national politics and guidelines, legal regulations, but the higher education institutions can play a bigger role.

During the establishment of a program, for instance, Master of Law program, higher university is able to create the study programme that includes study courses based on Legal Tech and innovation in particular area. The current topics on Legal Tech can be included in to the study course as well (Ryan, 2020). For example, a study course Environmental law can be based on Legal Tech applications, systems, etc. During the educational process, students can work with Legal Tech systems and solve legal problems based on the innovative approach. The European Commission supports in Estonia an established Legal Tech. - A.I. powered legal service platform of Lawyers was created HUGO.legal (European Comission, 2020). Legal program Legium - the legal platform to sign online legal contracts on blockchain. There are several professional legal document drafting programmes. Professional lawyers work a lot with legal documents. During the educational process, especially on professional level programs, during the 
practical classes, lecturers pay big attention to the improvement of students' legal skills in a particular area. However, it must be noted that over time, technologies demonstrate that there are more efficient ways to draft some legal documents. Some legal offices, even in Latvia are already working with tools like text templates or "speech-to-text". It can be mentioned that Legal Tech's new document management tools can automatically input contextual data, generate texts, etc. (Mirrlees, Alvi, 2020).

It should be noted that to eliminate these and other problems of modern legal education in terms of application of Legal Tech tools in the educational process, in Ukraine, the first steps have been taken (Lindgren, 2018).

The term "legal tech" (short for "legal technology") is an area where legal practice and high technology meet, mainly through the creation and development of computer programs (offline and online applications, bots (including chatbots), scripts, search engines, and more) to increase the efficiency, speed, quality, convenience and economy of solving certain legal problems (Spector, Ohrazda, Van Schaack, Wiley, 2005). This combination of law and technology is largely achieved through the intelligent automation of the actions that need to be performed by a living person (who usually has legal education and/or relevant work experience). These actions include searching, editing/replacing, text, matching, finding similarities, translating into another language, analysis, interpretation, selection, decision making, and more (Online encyclopedia ukrainskogo legal tech, 2020).

For the first time in Ukraine: (On July 22-26), the first Legal Innovations Summer School (LISS) was held in a small town (Yaremche) next to the Ukrainian part of the Carpathian mountains. The School brought together university teachers from all over Ukraine, representatives of Ukrainian student chapters of the Legal Hackers movement, the best speakers and mentors from disrupting legal projects. LISS was organized by KYIV Legal Hackers, Ministry of Justice of Ukraine, USAID New Justice Program, and OSCE Project Coordinator in Ukraine (Ivanov, 2020).

Based on the LISS's work results, a unique comprehensive course was prepared in Ukraine which provides systematic knowledge, practical skills in innovative legal technologies and is recommended for implementation in the curricula of higher education institutions of Ukraine.

Thus, the course "Legal Innovation \& Technologies" is aimed at: 1) raising the level of technological awareness; 2) applying legal innovation and technology; 3) creating own Legal Tech projects; 4) ensuring the compliance of knowledge and skills of graduates with the realities of the market (Legal innovation, 2020).

The main objectives of the course include: 1) the information about existing legal innovations and technologies, trends in the market of legal innovations obtained by students; 2) practical skills of using existing innovative technological 
products in the field of law acquired by students; 3) searching skills in open sources and the analysis of the received information acquired by students; 4) skills of drawing up legal documents using technologies, understanding the peculiarities of resolving disputes online acquired by students; 5) the information on the basics of cybersecurity in Ukraine and the EU obtained by students; 6) peculiarities of commercialization of startups, raising funds, etc comprehended by students (Ivanov, 2020).

It is proposed that the basics of "Legal Innovation \& Technology" are taught using traditional forms of learning such as lectures, workshops, workshops, group classes, and independent work (Jackson, 2016). The course program offers students to study relevant and nonclassical jurisprudence disciplines, such as: 1) introduction to legal innovation and technologies (evolution of digitalization of law; digitalization as a non-stop process; basic concept and categories/typology of digitalization of law; trends of legal innovation in Ukraine and the world; landscape Legal Tech projects in Ukraine (e-court); 2) design thinking (design thinking as a tool for solving cases in legal practice; design thinking as a tool for legal innovation); 3) algorithmization and automation in law (algorithmization and automation of processes in law; neural networks as a means of algorithmization and automation in law; chat (web) bots), etc. (Ivanov, 2020).

It is planned that based on the results of the training, the student will be able to create a chatbot, a crypto wallet, a road map of a project, to visualize the procedure of online dispute resolution, to offer an own startup in this area. In other words, to master the skills of a legal engineer.

In the market of educational services of Ukraine, students or lawyers who already have work experience and want to gain or deepen their knowledge in Legal Tech, the certificate programs are also offered. Such courses include: "Information Technology Law" program of the National University of "KyivMohyla Academy" and the Association "IT Ukraine" (Information Technology Law, 2020); Ukrainian-American program on legal aspects of business in IT "Institute of Law Technology and Innovation" (ILTI), launched in 2015 (Institute of Law Technology and Innovation, 2020) and others.

In the market of educational services of Latvia, there are just two law schools which provide to law students minimums of Legal Tech based study. There are not any certificate programs offered based on Legal Tech implementation during the educational process. There are some law schools which provide program Technology Law (Riga Graduate School of Law, 2020), there are two law schools, universities which provide study courses based on information technology law (Riga Stradiņš university, 2020). However, in common, there are lack of Legal Tech implementation in legal education system. The digitalization process places a greater burden on educational institutions and provides new challenges from the technological progress. Historically, digital transformation has been under 
discussion in other spheres, but now this is topical issues for the legal industry as well around the world (Palkova, 2020).

The research confirms that currently most law schools, universities in Latvia and in Ukraine do not offer any technologically advanced Legal Tech options to explore legal technologies. The practice of law is developing very fast, nevertheless the legal education system stays at $20^{\text {th }}$ century level. There is a vital need from the legal profession future perspective to provide students with the opportunity to implement and learn Legal Tech during the education process.

\section{Conclusions}

Legal Tech in Education in Ukraine and in Latvia is still at the stage of its formation. The first steps in launching it in legal education have been taken, but the implementation of this tool in the curricula of higher legal education institutions, the opening of faculties that train "legal engineers" and the approval of a new direction of the legal profession "legal engineer" at the legislative level remain unresolved.

The legal profession and legal practice are developing faster than legal education system. As a result, new lawyers are not prepared for the technological progress provided by Legal Tech.

The potential transformation of the existing legal profession is closely linked to legal education. Nowadays, law schools' graduates trying to enter the profession from the future challenges' perspective. Legal education system now is fundamentally different from that of the future and previous generations.

The legislation of both Latvia and Ukraine just indirectly regulates the application of Legal Tech in higher education institutions of the legal field. We are convinced that the Concept for the Development of Legal Education should become a document that will regulate the use of the Legal Tech tool during the training of law students, as well as the launch of special training courses on technological literacy of lawyers (certified educational program, faculty training legal engineers, etc.).

There are two groups of law schools: law schools that started to provide to law and technology related courses which promoted student engagement with legal tech. And law schools that do not provide any Legal Tech related courses. As the Legal Tech is not mandatory and not enshrined in law, there is a risk of stagnation of the legal profession. Cooperation with higher education institutions, the Ministry of Justice, Ministry of Education and Science, National Collegium of Sworn Advocates, lawyers, etc. is vital to implement the Legal Innovations \& Technologies or Legal Tech related courses in the legal education system. The single an officially approved program recommended for implementation in higher education institutions can give real outcomes. 
SOCIETY. INTEGRATION. EDUCATION

Proceedings of the International Scientific Conference. Volume V, May $28^{\text {th }}-29^{\text {th }}$, 2021. 414-425

Modern lawyers should consider new technologies as a source of great opportunities for development. However, to reap the benefits of such opportunities, a future lawyer needs to master a new level of literacy in this digitalized world. The main task of higher education institutions is to quickly adapt to these conditions and offer an educational product that can meet the needs of the European labor market.

\section{References}

Abroski, V., (2020) Concept for the Development of Legal Education. Retrieved from http://oduvs.edu.ua/news/the-concept-of-the-development-of-legal-education-viewsopinions-contradictions/.

Andrade, M., de Dionísio, R., de Castro, B., Pinto, E., de Castro, R.G. (2020). Legal tech: analytics, inteligência artificial e as novas perspectivas para a prática da advocacia privada. Retrieved from http://www.scielo.br/pdf/rdgv/v16n1/2317-6172-rdgv-16-01e1951.pdf

Betts, K.D., \& Jaep, K.R. (2017). The Dawn of Fully Automated Contract Drafting: Machine Learning Breathes New Life Into a Decades-Old Promise, 15 Duke Law \& Technology Review 216-233. Retrieved from https://scholarship.law.duke.edu/cgi/viewcontent.cgi? article $=1306 \&$ context $=$ dltr

Cabinet of the Ministers of Ukraine. (2020). Programma dejatelnosti Kabineta ministrov Ukraini. Retrieved from http://old.kmu.gov.ua/kmu/control/ru/publish/article?art_id= 247809614\&cat_id=246935189

Corrales, M., Forgo N., Kono T., (2020). Legal Tech and the New Sharing Economy. Perspectives in Law, Business and Innovation. (34-39). Springer Nature Singapore Pte Ltd. ISSN: 2520-1875.

Education Law. (1999). The Saeima has adopted and the President has proclaimed 24.12.1998. Retrieved from https://likumi.lv/ta/en/en/id/50759.

European Comission. (2020). Hugo.legal. Retrieved from https://ec.europa.eu/eipp/ desktop/lv/projects/project-11726.html

Fenwick, W.A., Kaal, E.P.M. (2020). Vermeulen Legal Education in a Digital Age. Springer Nature Singapore Pte Ltd, 103-122. Retrieved from https:/www.scopus.com/ record/display.uri?eid=2-s2.0-85076745875\&origin=inward\&txGid=52b9f5700939eec 8a130cbba5dca06b4

Friedel, R. (2007). A Culture of Improvement: Technology and the Western Millennium. Cambridge, MA: MIT Press.

Grasis, J., (2020). New challenges for the legal education in Latvia. SOCIETY. INTEGRATION. EDUCATION. Proceedings of the International Scientific Conferenc, Volume I, May 22th-23th, 2020, 181-189. Retrieved from: http://journals.rta.lv/index.php/SIE/ article/view/5001/4455

Hartung, M., Bues M., Halbleib G. (2018). Legal Tech: A Practitioner's Guide. (334-372). Bloomsbury Academic.

Hughes, T. (2004). Human-Built World: How to Think About Technology and Culture. The British Journal for the History of Science 39(03), 441 - 442. Retrieved from: https://www.researchgate.net/publication/231876209_THOMAS_P_HUGHES_HumanBuilt_World_How_to_Think_about_Technology_and_Culture_Chicago_2004_review 
Palkova \& Agapova, 2021. Legal Tech in Legal Education: Global Perspectives and Challenges from the Latvian - Ukrainian Experience

Institute of Law Technology and Innovation. (2020). Filling the Technology Gap in the Legal Sector: The Need for Future Training. Retrieved from: https://ti.institute/2020/11/theneed-for-future-training/

Ivanov, D., (2020). Legal Innovations Summer School. Retrieved from https://medium.com/ @denisivanov_41111/how-liss-boosted-legal-education-globally-de8f57d3b3a7

Jackson, D. (2016). Human-centered legal tech: integrating design in legal education. Law Teacher, 82-97. Retrieved from: https://www.tandfonline.com/doi/full/10.1080/ 03069400.2016.1146468?scroll=top\&needAccess=tru

Lindgren, K. (2018). The Future of Australian Legal Education: A Collection. Thomson Reuters (Professional), Australia Limited.

McFaul, H., FitzGerald, E., Byrne, D. et al., (2020). A mobile app for public legal education: a case study of co-designing with students. RESEARCH IN LEARNING TECHNOLOGY Volume: 28, Article Number: 2434. DOI: 10.25304/rlt.v28.2434.

Ministry of Environmental Protection and Regional Development of the Republic of Latvia. (2021). Digital Transformation Guidelines for 2021-2027. Retrieved from https:/www.varam.gov.lv/lv/digitalas-transformacijas-pamatnostadnes-20212027gadam

Mirrlees, T., Alvi, Sh. (2020). Automating and Globalizing Higher Education in the Digital Age, 165-175. Taylor \& Francis. Routledge.

Moller, L., Huett, J., Harvey, DM. (2009). Learning and Instructional Technologies for the 21st Century. Visions of the Future, (15-99. Springer Science Business Media, LLC 2. USA. DOI 10.1007/978-0-387-09667-4

Online encyclopedia ukrainskogo legal tech. (2020). Як влаштований legal tech? Retrieved from: https://legaltech.org.ua/structure/

Palkova, K. (2020). Doktorantūras kvalitāte: izaicinājumi un nākotnes perspektīvas. SOCIETY. INTEGRATION. EDUCATION Proceedings of the International Scientific Conference. Volume II, May 22th -23th, 2020, 204-213. Retrieved from:http://journals.ru.lv/ index.php/SIE/article/view/4839/4501

President of Ukraine. (2019). Pro Tsili staloho rozvytku Ukrainy na period do 2030 roku. Presidential order. Ukaz Preydenta Ukrainy vid 30.09.2019 № 722/2019. Ofitsiinyi visnyk Ukrainy. 2019. № 79. St. 2712.

Komitet Verhovnoj Radi Ukraini. (2020). Proiekt kontseptsii rozvytku yurydychnoi osvity, (2020).Retrieved from http://kno.rada.gov.ua/news/main_news/75465.html

Riga Graduate School of Law. (2021). The Technology Law. Retrieved from https://www.rgsl.edu.lv/programmes/technology-law

Riga Stradiňš university. (2021). Information Society Rights (JF_392). Retrieved from https://www.rsu.lv/en/rsu-courses/information-society-rights-jf392

Ryan, F., (2020). Rage against the machine? Incorporating legal tech into legal education, The Law Teacher. DOI: 10.1080/03069400.2020.1805927.

Spector, M.J., Ohrazda, C., Van Schaack, A., Wiley, A. (2005). Innovations in Instructional Technology. Essays in Honor of M. David Merrill, 224 - 229. Taylor \& Francis e-Library. Lawrence Erlbaum Associates, Inc.

Vermeulen, E., Fenwick, M., \& Kaal, W. (2020). Legal education in a digital age: Why coding matters for the lawyer of the future. In The innovation economy and the law Why Coding Matters for the Lawyer of the Future. Elsevier B.V.

Vilks, A. (2019). New challenges for legal education. Socrates. Electronic Scientific Journal of Faculty of Law of R̄̄ga Stradiňš University, 2(14), 53-62. 